\title{
ARE THE DISINFECTANTS USED IN HOSPITALS ALSO EFFECTIVE ON BACTERIA THAT CAUSE NOSOCOMIAL INFECTIONS?: A UNIVERSITY HOSPITAL INVESTIGATION
}

\author{
HASTANEDE KULLANILAN DEZENFEKTANLAR NOZOKOMIYAL ENFEKSIYYON \\ ETKENİ BAKTERILER ÜZERINE DE ETKILI Mİ?: BIR ÜNIVVERSITE HASTANESI \\ GÖZLEMI
}

\section{Çiğdem YAVAŞ ${ }^{1} \mathbb{( D}$, Fatma KAYNAK-ONURDAĞ $\check{2}^{*}$ (D), Suzan ÖKTEN²}

${ }^{1}$ Trakya University, Health Center for Medical Research and Practice, 22030, Edirne, Turkey

${ }^{2}$ Trakya University, Faculty of Pharmacy, Department of Pharmaceutical Microbiology, 22030, Edirne, Turkey

\begin{abstract}
Objective: Determining the disinfectant activity regularly will result in proper disinfection. In our study, it was aimed to determine the efficacy, effective concentrations and durations of some disinfectants used in Trakya University Hospital against nosocomial bacteria isolated from the same center.

Material and Method: MRSA, VRE, Klebsiella pneumoniae and Acinetobacter baumannii isolates and 10 different disinfectants supplied from the same center were included in the study. Susceptibility tests and Qualitative Suspension Test were applied through the guidelines of CLSI M100-S25 and TS/EN/1040:2005 (formerly TS/EN/1040:1999), respectively. Qualitative Suspension Test was modified by using D/E Neutralizing Broth instead of adding a neutralizing agent.

Result and Discussion: As a result, it was determined that all isolates were susceptible in the application conditions. However, peracetic acid, sodium dichloroisocyanurate, non-ionic active agent and sodium hypochlorite containing disinfectants being used in the hospital were not effective against some strains isolated from the hospital. Even the resistance of a single isolate to the application conditions of a disinfectant may lead to selection and proliferation of the strains and this may cause hospital infections. Our results might provide a reference to indicate the importance of selecting appropriate disinfectants and appropriate conditions for cleaning and disinfection in hospitals. $V R E$

Keywords: Acinetobacter baumannii, ESBL, Klebsiella pneumoniae, MRSA, Qualitative Suspension Test,
\end{abstract}

\footnotetext{
* Corresponding Author/Sorumlu Yazar: Fatma Kaynak Onurdağ

e-mail / e-posta: fatmakaynak@trakya.edu.tr, Phone / Tel.: +90 2842350180 / 2192
} 


\section{$\ddot{\mathbf{O Z Z}}$}

Amaç: Dezenfektan aktivitesinin düzenli aralıklarla belirlenmesi, uygun dezenfeksiyonla sonuçlanacaktır. Çalışmamızda Trakya Üniversitesi Hastanesinde kullanılan bazı dezenfektanların aynı merkezden izole edilen nozokomiyal bakterilere karşı etkinlik, etki konsantrasyonları ve sürelerinin belirlenmesi amaçlanmıştır.

Gereç ve Yöntem: MRSA, VRE, Klebsiella pneumoniae ve Acinetobacter baumannii izolatları ile aynı merkezden temin edilen 10 farklı dezenfektan çalışmaya dahil edildi. Dirençli oldukları, CLSI önerileri doğrultusunda yapılan duyarlılık ve doğrulama testleri ile gösterilen izolatlar çalışmaya alınmıs ve dezenfektan etkinliği TS/EN/1040:2005 (eski adıyla TS/EN/1040:1999) önerileri doğrultusunda kalitatif süspansiyon testi ile saptanmıştır.

Sonuç ve Tartışma: Sonuç olarak perasetik asit, sodyumdikloroizosiyanurat, non-iyonik aktif madde ve sodium hipoklorit hastaneden izole edilen bazı izolatlar üzerine etkisiz bulunmuştur. Uygulama koşullarında, bir dezenfektanın etki etmediği tek bir izolatın olması bile, bu suşun seçilimine ve çoğalmasına neden olarak hastane enfeksiyonlarına sebep olabilir. Bu nedenle, sonuçlarımızın, hastanelerde uygun dezenfektanların, uygun koşullarda uygulanmasl ve hastane görülen izolatlar üzerinde de test edilmesi gerektiğini göstermesi açısından önemli olduğu düşünülmektedir.

Anahtar Kelimeler: Acinetobacter baumannii, ESBL, kalitatif süspansiyon testi, Klebsiella pneumoniae, $M R S A, V R E$

\section{INTRODUCTION}

Disinfection is the process of destroying microorganisms except the spores of spore-forming bacteria, on inanimate objects [1] and it may ensure the safe use of the instruments in a hospital when applied in the appropriate conditions [2]. The resistance of microorganisms to chemical and physical processes depends on their biochemical structures and their protection mechanisms. For this reason, although vegetative bacteria are generally susceptible to disinfectants, some may resist to certain agents [2-7]. Many Gram negative and Gram positive bacteria including Acinetobacter spp., Klebsiella spp., Staphylococcus aureus and Enterococcus spp. survive on dry environmental surfaces for several months and cause hospital infections [8]. Contaminated surfaces in a hospital are the major causes in the transmission of nosocomial infections caused by antibiotic resistant bacteria.These infections vary from patient to patient or between two clinical presentations. In this case, the chemicals to be used must be effective on the resistant bacteria [9]. It is necessary that disinfectants can be reliably tested with microorganisms existing in the hospital environment and that the application method and application concentrations can be accurately determined [9]. Under the control of the hospital infection committees, disinfectants should be purchased by detecting effective disinfectants against existing microorganisms. Proper disinfectant detection may only be possible if the disinfectant activity is determined using appropriate and reliable methods on bacterial isolates from the hospital environment [9].The type, number and localization of microorganisms; the type, density, contact duration of the disinfectant; many factors such as physical-chemical properties of the environment (heat, $\mathrm{pH}$, organic-inorganic materials), presence of biofilm, properties of materials and surfaces affect the disinfection processes [10]. Since these properties affect the process and also, continuous use of a selected disinfectant may lead to the 
development of resistant microorganisms, evaluation of resistance status should be made at certain intervals [2, 5-8, 11-15]. The basics of prevention and control of hospital infections are control methods such as hand hygiene, disinfection, sterilization, patient isolation, cleaning, in particular surveillance $[13,16]$.

In our study, it was aimed to determine the application concentrations and durations of the disinfectants used in Trakya University Hospital against bacteria isolated from the same center. Therefore, Methicillin Resistant Staphylococcus aureus (MRSA), Vancomycin Resistant Enterococcus spp. (VRE), Klebsiella pneumoniae and Acinetobacter baumannii isolates, which are important in terms of hospital infections and also for our hospital, were included in the study. In addition, the periods and concentrations in which they were active were determined and interpreted with their activity in the time and concentration being used.

\section{MATERIAL AND METHOD}

\section{Microorganisms}

Clinical isolates were collected from Trakya University Hospital. Isolates were corrected to be $A$. baumannii, K. pneumoniae, S. aureus and E. faecalis by using Biomerieux Api ${ }^{\circledR} 20 \mathrm{NE}$, Microgen ${ }^{\circledR}$ GN-ID A, Microgen ${ }^{\circledR}$ Staph-ID and Microgen ${ }^{\circledR}$ Strep-ID identification kits, respectively. After identification, isolates were stored in Microbank ${ }^{\mathrm{TM}}$ cryovials at $-80^{\circ} \mathrm{C}$.

Among thirty-one $K$. pneumonia isolates, 14 were detected to have extended spectrum beta lactamase enzyme (ESBL). Fifteen MRSA isolates, 14 VRE isolates and 25 "carpapenem and ciprofloxacin" resistant A. baumannii isolates were included in the study. Isolated strains were provided from different units of the hospital from different tissue samples.

\section{Susceptibility Testing}

Cefoxitin disc diffusion test, ESBL confirmatory test and microdilution methods were applied through the guidelines of CLSI M100-S25 to determine the susceptibilities of the isolates [17]. ESBL confirmatory test was applied to K. pneumoniae isolates and ceftazidim, ceftazidim/clavulanic-acid, cefotaxim and cefotaxim/ clavulanic-acid were used to confirm the enzyme activity [17]. Cefoxitin disc diffusion test was applied to $S$. aureus isolates to show methicillin resistance [17].

In microdilution method, Pseudomonas aeruginosa ATCC 27853, Escherichia coli ATCC 25922, S. aureus ATCC 29213, E. faecalis ATCC 29212 standard strains were used as quality control strains. Meropenem (Sigma), imipenem (Sigma), ciprofloxacin (Sigma), vancomycin (Biomatik), ampicillin (Biomatik), gentamicin (Sigma), and ceftazidim (Sigma) solutions were prepared and susceptibilities of the isolates through the agents were determined [17]. 


\section{Disinfectant Efficacy Testing}

P. aeruginosa ATCC 15442, E. coli ATCC 11229, Proteus mirabilis ATCC 14153, K. pneumoniae ATCC 4352, S. aureus ATCC 6538 quality control strains and the isolates were used. Commercial disinfectants containing orthophthalaldehyde, peracetic acid, sodium dichloroisocyanurate, isopropanol, ethanol, benzalkonium chloride, glucoprotamine, quaternary ammonium propionate, sodium hypochlorite which are used in Trakya University Hospital were included in the study. Since it is intended to investigate the effectiveness of the actual conditions applied at the hospital, commercial disinfectant agents were used in their packaged forms with the conditions applied in our hospital through the manufacturers' recommendations.

The disinfectants and conditions which the disinfectants are applied in our hospital are given in Table 1.

Table 1. Conditions which the disinfectants are applied in our hospital

\begin{tabular}{|c|c|c|c|c|c|}
\hline Disinfectant & $\begin{array}{l}\text { Purpose of } \\
\text { disinfection }\end{array}$ & Active Ingredient & $\begin{array}{c}\text { Formulation } \\
\text { Tested }\end{array}$ & $\begin{array}{c}\text { Application } \\
\text { Procedure }\end{array}$ & $\begin{array}{c}\text { Contact } \\
\text { Time }\end{array}$ \\
\hline D1 & Medical devices & Orthophthalaldehyde & Undiluted & $\begin{array}{l}\text { Immersing in the } \\
\text { solution }\end{array}$ & $5 \mathrm{~min}$ \\
\hline D2 & Medical devices & Peracetic acid & $2 \%$ & $\begin{array}{c}\text { Immersing in the } \\
\text { solution }\end{array}$ & $5 \mathrm{~min}$ \\
\hline D3 & $\begin{array}{l}\text { Water tanks and } \\
\text { surfaces exposed to } \\
\text { organic pollution }\end{array}$ & $\begin{array}{c}\text { Sodium } \\
\text { dichloroisocyanurate }\end{array}$ & $\begin{array}{c}2 \text { tablets/ } \\
1 \text { liter tab water }\end{array}$ & $\begin{array}{c}\text { Throwing into } \\
\text { water and/or } \\
\text { immersing in the } \\
\text { solution }\end{array}$ & $10-15 \mathrm{~min}$ \\
\hline D4 & Surfaces & $\begin{array}{c}\text { Isopropanol, Ethanol, } \\
\text { Benzalkonium } \\
\text { chloride, } \\
\text { Glucoprotamine }\end{array}$ & Undiluted & $\begin{array}{l}\text { Spraying and } \\
\text { wiping on surfaces }\end{array}$ & - \\
\hline D5 & $\begin{array}{l}\text { Clean medical } \\
\text { instruments }\end{array}$ & $\begin{array}{c}\text { Ethanol, quaternary } \\
\text { ammonium } \\
\text { propionate }\end{array}$ & Undiluted & $\begin{array}{l}\text { Spraying on the } \\
\text { surface of the } \\
\text { instrument }\end{array}$ & - \\
\hline D6 & Hand [antiseptic] & Ethanol & Undiluted & $\begin{array}{l}\text { Rubbing over the } \\
\text { hands }\end{array}$ & $\begin{array}{c}30-45 \\
\text { seconds }\end{array}$ \\
\hline D7 & Surfaces & $\begin{array}{l}\text { Calcium carbonate, } \\
\text { anionic surfactant, } \\
\text { sodium carbonate, } \\
\text { benzyl alcohol }\end{array}$ & Undiluted & $\begin{array}{l}\text { Wiping on surfaces } \\
\text { and rinsing with } \\
\text { water }\end{array}$ & - \\
\hline D8 & WC-Bath & $\begin{array}{c}\text { Cationic surfactant } \\
\text { and } \mathrm{HCl}\end{array}$ & Undiluted & $\begin{array}{l}\text { Squeezing on the } \\
\text { curves of the } \\
\text { surface }\end{array}$ & - \\
\hline D9 & Floors & $\begin{array}{c}\text { Non-ionic and } \\
\text { anionic active agent }\end{array}$ & $\begin{array}{l}\text { 100gr or } 200 \mathrm{gr} \\
/ 8 \mathrm{lt} \mathrm{tab} \text { water }\end{array}$ & $\begin{array}{l}\text { Wiping with floor } \\
\text { mop }\end{array}$ & - \\
\hline D10 & Surfaces & Sodium hypochlorite & $5 \%$ & $\begin{array}{l}\text { Wiping with cloth } \\
\text { or applying directly } \\
\text { on the surface }\end{array}$ & - \\
\hline
\end{tabular}

\section{Qualitative Suspension Test}

Standard bacterial strains and clinical isolates were cultivated on Tryptic Soy Agar (TSA) (LabM) medium and incubated at $37^{\circ} \mathrm{C}$ for $18-24$ hours. The third passage of the culture was used in the 
qualitative suspension test. Solutions of disinfectants were prepared in at least three different concentrations. Stock solutions of the ready to use disinfectants were used as the first concentration without diluting. A stock solution of 2 times the application concentration was used for $D 3$ reach application concentration for this disinfectant as the $1 / 4$ dilution of the agent. All the disinfectant solutions were prepared fresh and tested with standard bacterial strains and clinical isolates at 3, 5, 10, 15, 20 and 30 minutes in clean and dirty conditions.

Qualitative suspension test was applied through the guidelines of TS/EN/1040:2005 (formerly TS/EN/1040:1999) [18]. The method was modified by using D/E Neutralizing Broth (Difco) instead of adding a neutralizing agent in a medium and 24 wells sterile microplates were used as reported by Kawamura-Sato et al. [19].

Bacterial inoculum was prepared at McFarland 0.5 concentrations $\left(1.5-5 \times 10^{8} \mathrm{CFU} / \mathrm{mL}\right)$ and these bacterial suspensions were used in the study. Disinfectant solutions were prepared with hard water.

\section{Preparation of Hard Water}

Solution A: $19.84 \mathrm{~g}$ anhydrous $\mathrm{MgCl}_{2}$ and $46.24 \mathrm{~g}$ anhydrous $\mathrm{CaCl}_{2}$ are dissolved in sterile distilled water with the final volume of $1000 \mathrm{~mL}$.

Solution B: $35.02 \mathrm{~g} \mathrm{NaHCO}_{3}$ is dissolved in sterile distilled water with the final volume of $1000 \mathrm{~mL}$. $600 \mathrm{~mL}$ of water was added to $6 \mathrm{~mL}$ of solution $\mathrm{A}$, and then $8 \mathrm{~mL}$ of $\mathrm{B}$ was added to this solution. Sterile distilled water was added up to $1000 \mathrm{~mL}$. This mixture was filtered through a milipore filter and sterilized. $\mathrm{pH}$ of the solution was set to $7.0 \pm 0.2$.

Applications were performed at $21^{\circ} \mathrm{C}$ temperature. Bovine albumin (Merck) solution was used at different concentrations for clean or dirty conditions as a decaying agent. Bovine albumin solution for clean conditions was prepared at $0.3 \mathrm{~g} / \mathrm{L}$, and for dirty conditions at $3 \mathrm{~g} / \mathrm{L}$ concentrations. All disinfectants were tested in both clean and dirty conditions.

Stock solutions of ready to use disinfectants were used without diluting. D3 and D10 were diluted with hard water.

The prepared disinfectant solutions were diluted with hard water containing appropriate amount of BSA for clean and dirty conditions. Dilution was performed in sterile 24-well microplates. There was $1 \mathrm{~mL}$ of disinfectant solution in every well of the plates after dilution. $100 \mu \mathrm{L}$, McFarland 0.5 density inoculum of bacteria were added to the wells and time was started immediately. After the selected contact time, the sample was transferred to D/E Neutralizing Broth to stop the disinfectant activity. After incubation at $37^{\circ} \mathrm{C}$ for $18-24$ hours, changing of the medium color from purple to yellow was considered as growth for fermentative bacteria. A. baumannii was recultivated on Tryptic Soy Agar to ensure growth.

If there was growth; the disinfectant was considered to be ineffective in the tested concentration at the tested time, and if there was no growth, the disinfectant was considered to be effective. 


\section{Statistical Analyses}

When 10 different disinfectants were applied on 4 different bacterial groups, it was revealed that there was a significant difference between the bacterial groups by Oneway ANOVA analysis $(\mathrm{p}<0.05)$.

\section{RESULT AND DISCUSSION}

In our study, the effect of disinfectants on resistant bacterial isolates at 3 different concentrations, including the concentration applied in the hospital, in clean and dirty conditions, and in different contact times was investigated.

As a result it was determined that all isolates were susceptible in the application conditions. However; peracetic acid, sodium dichloroisocyanurate, non-ionic active agent and sodium hypochlorite containing disinfectants being used in the hospital were not effective against some strains isolated from the hospital. Numbers of isolates susceptible to disinfectants in dirty and clean conditions at different contact times are shown in Table 2.

There are certain numbers of microorganisms that can be killed by a certain amount of disinfectant at a certain concentration. As the number of microorganisms increases, the concentration of disinfectant or contact time increases [2]. For these reasons, standardization has been carried out in the tests for the purpose of evaluating disinfectant activity. While showing differences between countries; parameters such as standard microorganism species, inoculum of microorganism, presence of organic matter, ambient temperature and $\mathrm{pH}$, and neutralization agents have been standardized [20-24]. In addition, the effects of environmental conditions on disinfectant activity were investigated in scientific studies and it was shown that different results were obtained for different species of microorganisms [25-27].

Various methods have been developed to determine the effectiveness of disinfectant agents. The tests that determine the effectiveness of disinfectants may be disinfectant activity tests or specific tests for the purpose. All methods have the same purpose. One or more of these methods are used depending on the organic or inorganic contaminants that may be present in the environment, the disinfectant application area, the microorganism spectrum to which it may be effective $[3,6,10,14,15,18,20,23]$. Suspension tests belong to the activity tests $[3,10,22]$ and are frequently used to determine the effectiveness of a disinfectant against bacteria after a specific contact period [15, 20, 28, 29, 31, 32].

Hospital infections are an important problem in our country as well as in the whole world, and attempts are being made to develop appropriate disinfection policies to prevent this problem. Proper selection and application of disinfectants and antiseptics may improve the quality of treatment by reducing the unnecessary use of antibiotics and the length of hospital stay.It is therefore very important to investigate efficacy of the disinfectants prior to the supply of these substances. However, disinfectants used in hospitals should also be effective against microorganisms associated with hospital infection [19, $32,33]$. 
Antimicrobial susceptibility of bacteria isolated from different hospital environments may differ from each other. Okesola and Olola investigated the efficacy of disinfectants on P. aeruginosa isolated from the same hospital and determined resistant and intermediate susceptible isolates to Chloroxylenol (Dettol) and sodium hypochlorite (JIK) containing disinfectants. They suggested not using or changing the application conditions of these two disinfectants [34].

Inan et al. have investigated the disinfectant efficacy to 10 isolates from each of E. coli, $P$. aeruginosa, Acinetobacter $s p$. and MRSAisolated from their hospital. They reported that ethyl alcohol was effective to MRSA isolates, Acinetobacter isolates and other isolates after 1st minute, 5th minute and 20th minute exposure, respectively. While $10 \%$ solution of povidon iodure was detected to be effective to all isolates, $1 \%$ solution was not effective to MRSA isolates at 1 and 5 minutes exposure. 1/25 diluted benzalkonium chloride was effective only to MRSA isolates. Phenolic compounds were effective after 20 minutes exposure and the most effective agents were determined to be sodium hypochlorite and glutaraldehyde to all isolates [35].

Eryilmaz $\mathrm{M}$ et al., have also studied the efficacy of some disinfectants to nosocomial infection causing bacteria by quantitative suspension test. All of the isolates from their hospital were found to be susceptible to $2 \%$ glutaraldehyde, $4 \%$ chlorhexidine gluconate, $7.5 \%$ povidone-iodine, $10 \%$ povidoneiodine and 70\% 2-propanole in all conditions. However, they determined resistant isolates to $3 \% \mathrm{H}_{2} \mathrm{O}_{2}$ even after 10 minutes exposure. As a result of this study they commented that the studied disinfectants being used in their hospital may be kept using; however $3 \% \mathrm{H}_{2} \mathrm{O}_{2}$ should not be used because of the resistant isolates [2].

In our study, the effect of disinfectants on resistant bacterial isolates at 3 different concentrations, including the concentration applied in the hospital, in clean and dirty conditions, and in different contact times was investigated. As a result it was determined that all isolates were susceptible to D4, D5, D6, D7 and D8 in the application concentration and time, in both dirty and clean conditions. So, it has been determined that these disinfectants are efficient for disinfection in our hospital.

D4 contains glucoprotamine as the active ingredient and Tyskiet al., who investigated the activity of glucoprotamine not only on standard strains but also on clinical isolates, reported that it was effective to all bacterial and fungal isolates at short time intervals [36]. This finding is also compatible with the results of our study.

All bacterial isolates were susceptible to D1 in the stock solution, in both clean and dirty conditions at 5 minutes application. However, 10 Acinetobacter isolates were determined not to be susceptible to this agent in the $1 / 4$ diluted concentration of the stock solution in dirty conditions at 5,10 , 15 minutes applications. In clean conditions, the number of non-susceptible Acinetobacter isolates were 6, 4 and 3, at 5, 10, 15 minutes intervals, respectively. While 3 of the ESBL isolates were resistant to the $1 / 2$ diluted concentrations in both dirty and clean conditions up to 15 minutes, all ESBL isolates were 
resistant to D1 in $1 / 4$ diluted concentrations. MRSA and VRE isolates were determined to be susceptible to this disinfectant in all conditions. These findings show that D1 is an effective disinfectant when the stock solution is used as applied in our hospital.

Table 2. Number of isolates susceptible to disinfectants in dirty and clean conditions at different contact times

\begin{tabular}{|c|c|c|c|c|c|c|c|c|c|}
\hline \multirow[t]{2}{*}{ Disinfectant } & \multirow[t]{2}{*}{ Condition } & \multirow[t]{2}{*}{ Dilution } & \multirow[t]{2}{*}{ Bacteria } & \multicolumn{6}{|c|}{ Time (Minutes) } \\
\hline & & & & $3^{\prime}$ & $5^{\prime}$ & ${ }^{\prime 10^{\prime}}$ & ${ }^{\prime 15^{\prime}}$ & $20^{\prime}$ & 30 \\
\hline & & & & & & & & & \\
\hline \multirow{25}{*}{$\bar{\Omega}$} & \multirow{13}{*}{ Dirty } & \multirow{4}{*}{1} & $\mathrm{~K}$ & 14 & 14 & 14 & 14 & 14 & 14 \\
\hline & & & $\mathrm{A}$ & 25 & 25 & 25 & 25 & 25 & 25 \\
\hline & & & $\mathrm{E}$ & 15 & 15 & 15 & 15 & 15 & 15 \\
\hline & & & $\mathrm{S}$ & 14 & 14 & 14 & 14 & 14 & 14 \\
\hline & & \multirow{4}{*}{$1 / 2$} & $\mathrm{~K}$ & 10 & 11 & 11 & 11 & 14 & 14 \\
\hline & & & A & 24 & 25 & 25 & 25 & 25 & 25 \\
\hline & & & $\mathrm{E}$ & 15 & 15 & 15 & 15 & 15 & 15 \\
\hline & & & $\mathrm{S}$ & 14 & 14 & 14 & 14 & 14 & 14 \\
\hline & & \multirow{5}{*}{$1 / 4$} & $\mathrm{~K}$ & 0 & 0 & 0 & 0 & 14 & 14 \\
\hline & & & $\mathrm{A}$ & 13 & 15 & 15 & 15 & 25 & 25 \\
\hline & & & $\mathrm{E}$ & 15 & 15 & 15 & 15 & 15 & 15 \\
\hline & & & $\mathrm{S}$ & 14 & 14 & 14 & 14 & 14 & 14 \\
\hline & & & & & & & & & \\
\hline & \multirow{12}{*}{ Clean } & \multirow{4}{*}{1} & $\mathrm{~K}$ & 14 & 14 & 14 & 14 & 14 & 14 \\
\hline & & & $\mathrm{A}$ & 25 & 25 & 25 & 25 & 25 & 25 \\
\hline & & & $\mathrm{E}$ & 15 & 15 & 15 & 15 & 15 & 15 \\
\hline & & & $\mathrm{S}$ & 14 & 14 & 14 & 14 & 14 & 14 \\
\hline & & \multirow{4}{*}{$1 / 2$} & $\mathrm{~K}$ & 10 & 10 & 11 & 11 & 14 & 14 \\
\hline & & & $\mathrm{A}$ & 25 & 25 & 25 & 25 & 25 & 25 \\
\hline & & & $\mathrm{E}$ & 15 & 15 & 15 & 15 & 15 & 15 \\
\hline & & & $\mathrm{S}$ & 14 & 14 & 14 & 14 & 14 & 14 \\
\hline & & \multirow{4}{*}{$1 / 4$} & $\mathrm{~K}$ & 0 & 0 & 0 & 0 & 14 & 14 \\
\hline & & & $\mathrm{A}$ & 17 & 19 & 21 & 22 & 25 & 25 \\
\hline & & & $\mathrm{E}$ & 15 & 15 & 15 & 15 & 15 & 15 \\
\hline & & & $\mathrm{S}$ & 14 & 14 & 14 & 14 & 14 & 14 \\
\hline \multirow{18}{*}{$\tilde{ก}$} & \multirow{12}{*}{ Dirty } & \multirow{4}{*}{1} & $\mathrm{~K}$ & 0 & 0 & 11 & 11 & 12 & 13 \\
\hline & & & $\mathrm{A}$ & 1 & 1 & 6 & 8 & 10 & 13 \\
\hline & & & $E$ & 0 & 0 & 15 & 15 & 15 & 15 \\
\hline & & & $\mathrm{S}$ & 0 & 0 & 14 & 14 & 14 & 14 \\
\hline & & \multirow{4}{*}{$1 / 2$} & $\mathrm{~K}$ & 0 & 0 & 6 & 5 & 5 & 6 \\
\hline & & & $\mathrm{A}$ & 0 & 0 & 0 & 0 & 0 & 0 \\
\hline & & & $\mathrm{E}$ & 0 & 0 & 6 & 9 & 9 & 11 \\
\hline & & & $\mathrm{S}$ & 0 & 0 & 1 & 6 & 6 & 9 \\
\hline & & \multirow{4}{*}{$1 / 4$} & $\mathrm{~K}$ & 0 & 0 & 0 & 0 & 1 & 4 \\
\hline & & & $\mathrm{A}$ & 0 & 0 & 0 & 0 & 0 & 0 \\
\hline & & & $E$ & 0 & 0 & 3 & 3 & 3 & 4 \\
\hline & & & $\mathrm{S}$ & 0 & 0 & 0 & 0 & 0 & 5 \\
\hline & \multirow{6}{*}{ Clean } & \multirow{4}{*}{1} & $\mathrm{~K}$ & 0 & 0 & 12 & 13 & 13 & 13 \\
\hline & & & $\mathrm{A}$ & 1 & 1 & 9 & 12 & 17 & 20 \\
\hline & & & $\mathrm{E}$ & 0 & 0 & 15 & 15 & 15 & 15 \\
\hline & & & $\mathrm{S}$ & 0 & 0 & 14 & 14 & 14 & 14 \\
\hline & & $1 /$ & $\mathrm{K}$ & 0 & 0 & 3 & 7 & 7 & 9 \\
\hline & & $1 / 2$ & $\mathrm{~A}$ & 1 & 1 & 1 & 1 & 1 & 1 \\
\hline
\end{tabular}


Table 2 (continued). Number of isolates susceptible to disinfectants in dirty and clean conditions at different contact times.

\begin{tabular}{|c|c|c|c|c|c|c|c|c|c|}
\hline & & & E & 0 & 0 & 15 & 15 & 15 & 15 \\
\hline & & & $S$ & 0 & 0 & 14 & 14 & 14 & 14 \\
\hline & & \multirow{4}{*}{$1 / 4$} & $\mathrm{~K}$ & 0 & 0 & 0 & 2 & 2 & 3 \\
\hline & & & A & 0 & 0 & 0 & 0 & 0 & 0 \\
\hline & & & $E$ & 0 & 0 & 6 & 10 & 11 & 11 \\
\hline & & & $S$ & 0 & 0 & 5 & 13 & 14 & 14 \\
\hline \multirow{24}{*}{$\tilde{\Omega}$} & \multirow{12}{*}{ Dirty } & \multirow{4}{*}{1} & $\mathrm{~K}$ & 0 & 0 & 1 & 1 & 1 & 1 \\
\hline & & & A & 0 & 0 & 0 & 2 & 6 & 9 \\
\hline & & & $E$ & 0 & 0 & 12 & 15 & 15 & 15 \\
\hline & & & $S$ & 1 & 1 & 14 & 14 & 14 & 14 \\
\hline & & & $\mathrm{K}$ & 0 & 0 & 0 & 0 & 1 & 1 \\
\hline & & $1 / 2$ & A & 0 & 0 & 0 & 0 & 2 & 5 \\
\hline & & 12 & E & 0 & 0 & 2 & 2 & 2 & 2 \\
\hline & & & $S$ & 1 & 1 & 14 & 14 & 14 & 14 \\
\hline & & & $\mathrm{K}$ & 0 & 0 & 0 & 0 & 1 & 1 \\
\hline & & $1 / 4$ & A & 0 & 0 & 0 & 0 & 0 & 0 \\
\hline & & $8 / 4$ & $E$ & 0 & 0 & 2 & 2 & 2 & 2 \\
\hline & & & $\mathrm{S}$ & 1 & 1 & 14 & 14 & 14 & 14 \\
\hline & & & $\mathrm{K}$ & 0 & 0 & 1 & 1 & 1 & 1 \\
\hline & & 1 & A & 0 & 0 & 5 & 8 & 10 & 14 \\
\hline & & 1 & $E$ & 0 & 0 & 15 & 15 & 15 & 15 \\
\hline & & & $S$ & 1 & 1 & 14 & 14 & 14 & 14 \\
\hline & & & $\mathrm{K}$ & 0 & 0 & 1 & 1 & 1 & 1 \\
\hline & Clean & $1 / 2$ & A & 0 & 0 & 1 & 2 & 2 & 6 \\
\hline & Civail & 12 & $E$ & 0 & 0 & 15 & 15 & 15 & 15 \\
\hline & & & $S$ & 1 & 1 & 14 & 14 & 14 & 14 \\
\hline & & & $\mathrm{K}$ & 0 & 0 & 0 & 0 & 1 & 1 \\
\hline & & $1 / 4$ & A & 0 & 0 & 1 & 1 & 2 & 2 \\
\hline & & $8 / 4$ & $E$ & 0 & 0 & 15 & 15 & 15 & 15 \\
\hline & & & $S$ & 1 & 1 & 14 & 14 & 14 & 14 \\
\hline & & & K & 0 & 0 & 13 & 13 & 13 & 13 \\
\hline & & 1 & A & 0 & 0 & 1 & 1 & 1 & 1 \\
\hline & & 1 & $E$ & 1 & 1 & 15 & 15 & 15 & 15 \\
\hline & & & $S$ & 1 & 1 & 14 & 14 & 14 & 14 \\
\hline & & & $\mathrm{K}$ & 0 & 0 & 8 & 8 & 8 & 8 \\
\hline & Dirty & $1 / 2$ & A & 0 & 0 & 1 & 1 & 1 & 1 \\
\hline & Dirty & $1 / 2$ & $E$ & 1 & 1 & 15 & 15 & 15 & 15 \\
\hline & & & $S$ & 1 & 1 & 14 & 14 & 14 & 14 \\
\hline & & & $\mathrm{K}$ & 0 & 0 & 7 & 7 & 7 & 7 \\
\hline & & $1 /$ & $\mathrm{A}$ & 0 & 0 & 1 & 1 & 1 & 1 \\
\hline a & & $1 / 4$ & $E$ & 1 & 1 & 14 & 15 & 15 & 15 \\
\hline$\theta$ & & & $\mathrm{S}$ & 1 & 1 & 14 & 14 & 14 & 14 \\
\hline & & & $\mathrm{K}$ & 0 & 0 & 13 & 13 & 13 & 13 \\
\hline & & 1 & A & 0 & 0 & 1 & 1 & 1 & 1 \\
\hline & & 1 & E & 1 & 1 & 15 & 15 & 15 & 15 \\
\hline & & & $\mathrm{S}$ & 1 & 1 & 14 & 14 & 14 & 14 \\
\hline & Clean & & $\mathrm{K}$ & 0 & 0 & 8 & 8 & 8 & 8 \\
\hline & & $1 / 2$ & A & 0 & 0 & 1 & 1 & 1 & 1 \\
\hline & & 12 & $E$ & 1 & 1 & 15 & 15 & 15 & 15 \\
\hline & & & $S$ & 1 & 1 & 14 & 14 & 14 & 14 \\
\hline & & & K & 0 & 0 & 6 & 6 & 6 & 6 \\
\hline & & 74 & A & 0 & 0 & 1 & 1 & 1 & 1 \\
\hline
\end{tabular}


Table 2 (continued). Number of isolates susceptible to disinfectants in dirty and clean conditions at different contact times.

\begin{tabular}{|c|c|c|c|c|c|c|c|c|c|}
\hline & & & E & 1 & 1 & 15 & 15 & 15 & 15 \\
\hline & & & $S$ & 1 & 1 & 14 & 14 & 14 & 14 \\
\hline \multirow{24}{*}{$\stackrel{\circ}{\circ}$} & \multirow{12}{*}{ Dirty } & \multirow{4}{*}{$1 / 2$} & $\mathrm{~K}$ & 0 & 0 & 3 & 3 & 3 & 5 \\
\hline & & & $\mathrm{A}$ & 0 & 0 & 3 & 4 & 6 & 12 \\
\hline & & & $E$ & 0 & 0 & 15 & 15 & 15 & 15 \\
\hline & & & $S$ & 1 & 1 & 14 & 14 & 14 & 14 \\
\hline & & \multirow{4}{*}{$1 / 4$} & K & 0 & 0 & 0 & 0 & 0 & 0 \\
\hline & & & A & 0 & 0 & 1 & 2 & 4 & 8 \\
\hline & & & $\mathrm{E}$ & 0 & 0 & 15 & 15 & 15 & 15 \\
\hline & & & $S$ & 1 & 1 & 13 & 13 & 13 & 13 \\
\hline & & \multirow{4}{*}{$1 / 8$} & $\mathrm{~K}$ & 0 & 0 & 0 & 0 & 0 & 0 \\
\hline & & & $\mathrm{A}$ & 0 & 0 & 0 & 0 & 0 & 2 \\
\hline & & & $E$ & 0 & 0 & 5 & 6 & 8 & 11 \\
\hline & & & $S$ & 1 & 1 & 13 & 13 & 13 & 13 \\
\hline & \multirow{12}{*}{ Clean } & \multirow{4}{*}{$1 / 2$} & $\mathrm{~K}$ & 1 & 1 & 10 & 10 & 10 & 11 \\
\hline & & & A & 1 & 1 & 15 & 19 & 19 & 23 \\
\hline & & & $\mathrm{E}$ & 0 & 0 & 15 & 15 & 15 & 15 \\
\hline & & & $S$ & 1 & 1 & 14 & 14 & 14 & 14 \\
\hline & & \multirow{4}{*}{$1 / 4$} & $\mathrm{~K}$ & 0 & 0 & 0 & 0 & 0 & 1 \\
\hline & & & $\mathrm{A}$ & 0 & 0 & 3 & 4 & 6 & 9 \\
\hline & & & $E$ & 0 & 0 & 15 & 15 & 15 & 15 \\
\hline & & & $S$ & 1 & 1 & 14 & 14 & 14 & 14 \\
\hline & & \multirow{4}{*}{$1 / 8$} & $\mathrm{~K}$ & 0 & 0 & 0 & 0 & 0 & 0 \\
\hline & & & A & 0 & 0 & 2 & 2 & 4 & 7 \\
\hline & & & $E$ & 0 & 0 & 15 & 15 & 15 & 15 \\
\hline & & & $S$ & 1 & 1 & 13 & 14 & 14 & 14 \\
\hline
\end{tabular}

*K: ESBL isolates, A: Carpapenem and ciprofloxacin resistant A. baumannii isolates, E: VRE isolates, S: MRSA isolates

Peracetic acid is used in the disinfection or sterilization of critical instruments requiring high level disinfection and its effect on bacterial biofilm and bacterial spores has also been reported [25,37]. Although, there is not much information about the effect of peracetic acid against resistant microorganisms, some studies have reported some limitations of peracetic acid against resistant bacteria $[38,39]$. D2 has been used in our hospital by immersing the medical devices in the stock solution (2\% concentration) of the disinfectant for 5 minutes. In our study, the $1 / 2$ and $1 / 4$ diluted concentrations of this stock solution was also included in the study. Unfortunately, it was determined that the applied condition was not effective to any of the isolates except 1 A. baumannii isolate, in neither dirty nor clean conditions. However, it was efficient to all MRSA and VRE isolates in case of 10 minutes application. 5 of the A. baumannii isolates were found to be resistant even after 30 minutes application. After 10 minutes 2 of the ESBL isolates and after 15, 20 and 30 minutes 1 of the ESBL isolate were resistant to D2. The disinfectant was effective to the standard strains; S. aureus ATCC 6538, K. pneumoniae ATCC 4352 and E. coli ATCC 11229 after 10 minutes application. As a result of our study it is not recommended to be used in the hospital environment in the recommended conditions because of its insufficiency to the multi-drug resistant isolates. Supporting our findings, Kampf et al., in their review 
of the literature, stated that peracetic acid used in endoscope disinfection is insufficient and resistant $K$. pneumoniae and P. aeruginosa cases are seen [38]. However, in another study, the effect of two commercially available disinfectants containing peracetic acid on the stainless steel surfaces contaminated with S. aureus, E. coli and Candida albicans was investigated. It was reported that there was no significant difference between these disinfectants in terms of microbial efficacy but D2 lost its stability from the fourth day [39]. So, the reason why D2 was not effective could be the loss of stability. In hospitals, as in many hospitals, disinfectants are supplied in their largest packages in order to be cost effective. In this case, opened disinfectants may cause deterioration of their stability due to various reasons during use. According to the results of our study and in accordance with this finding, our proposal is to recommend that, packaging size of the disinfectant depending on the frequency of use of commercially available disinfectants should also be mentioned in their manuals.

D9 and D10 are surface cleaners, so after wiping the surfaces, time is not calculated. D9 has been using on floor cleaning by wiping the floor with a cloth or applied directly. Except one of the isolates, all K. pneumoniae, MRSA and VRE isolates were detected to be susceptible to the first concentration of the disinfectant after 10 minutes application. However, when the dilution factor increases the number of the resistant isolates increased. A. baumannii isolates were resistant even to the first concentration of the disinfectant. So, while the disinfectant is efficient for MRSA, VRE and ESBL isolates after 10 minutes, it does not have any effect on A. Baumannii isolates, which is a great problem for nosocomial infections.

D10 contains 5\% sodium hypochlorite and has been used for wiping the floor with a mop. The application conditions were enough to kill the VRE and MRSA after 10 minutes; however, there were still resistant ESBL and A. baumannii isolates even after 30 minutes application. Sodium dichloroisocyanurate $(\mathrm{NaDCC})$ has been an alternative for sodium hypochlorite due to its low toxicity, its chlorine level being more stable and not being corrosive recently [40,41].

Type of the strain, virulence factors of the strain or the inappropriate storage conditions may have led the disinfectants lose its ability. But what ever happened as the reason, 4 of the studied disinfectants being used in the hospital are not effective against some drug resistant strains isolated from the hospital and also by statistical analyze, the difference of the effect on different bacterial isolates was found to be significant $(\mathrm{p}<0,05)$.

Regardless of the number of isolates, even the resistance of a single isolate to the application conditions of a disinfectant may lead to selection and proliferation of the strains which are not affected by the disinfectants used in the hospital and this may cause hospital infections. Our results might provide a reference to help selecting appropriate disinfectants for cleaning and disinfection in hospitals. 


\section{ACKNOWLEDGEMENT}

This study was financed by Trakya University Scientific Research Projects (TUBAP) Unit, 2015/125 coded project. We would like to thank to "Trakya University Health Centre for Medical Research and Practice" for providing the isolates and the disinfectant samples.

\section{AUTHOR CONTRIBUTIONS}

Conception: Ç.Y., F.K.O.; Design: Ç.Y., F.K.O.; Supervision: Ç.Y., F.K.O.; Resources: F.K.O.; Materials: Ç.Y.; Data collection and/or processing: Ç.Y., F.K.O., S.Ö.; Analysis and/or interpretation: Ç.Y., F.K.O.; Literature search: Ç.Y.; Writing manuscript: F.K.O., S.Ö.; Critical review: C..Y., F.K.O., S. O.; Other: -

\section{CONFLICT OF INTEREST}

The authors declare no conflict of interest.

\section{ETHICS COMMITTEE APPROVAL}

The study was approved by Trakya University Scientific Research and Ethics Committee 2015/57-05/04 numbered permission.

\section{REFERENCES}

1. Günaydın, M., Esen, S., Karadağ, A., Ünal, N., Yanık, K., Odabaşı, H., Birinci, A. (2014). In vitro antimicrobial activity of Medilox ${ }^{\circledR}$ super-oxidized water. Annals of Clinical Microbiology and Antimicrobials, 13, 29-34. [CrossRef]

2. Eryılmaz, M., Akın, A., Akan-Arıkan, O. (2011). Investigation of the efficacy of some disinfectants against Nosocomial Staphylococcus aureus and Enterococcus spp. isolates. Mikrobiyoloji Bülteni, 45(3), 454-460.

3. Çağlar, K. (2009). Dezenfektan Etkinliginin Ölçülmesinde Örnek Modeller (El Dezenfektanı ve Yüzey Dezenfektanı), DAS Kongre Kitabı, Bilimsel Tıp Yayınevi, p. 139-148.

4. Otter, J.A., Yezli, S., Salkeld, J.A.G., French, G.L., Path, F.R.C. (2013). Evidence that contaminated surfaces contribute to the transmission of hospital pathogens and an overview of strategies to address contaminated surfaces in hospital settings. American Journal of Infection Control, 41, 6-11. [CrossRef]

5. Samast1, M. (2008). Hastanelerde Dezenfeksiyon Kullanım Esasları, Yapılan Hatalar: Hastane Enfeksiyonlar1 Koruma ve Kontrol Sempozyum Dizisi, 60, 143-168. 
6. McDonnell, S., Russell, D. (1999). Antiseptic and disinfectants: Activity, action, and resistance. Clinical Microbiology Reviews, 12(1), 147-179. [CrossRef]

7. Şencan, I. (2003). Dezenfektanlara Direnç Sorunu ve Pratik Önemi, DAS Kongre Kitabı, Bilimsel Tip Yayınevi.

8. Kramer, A., Schwebke, I., Kampf, G. (2006). How long do nosocomial pathogens persist on inanimate surfaces? A systematic review. BMC Infectious Diseases, 6, 130. [CrossRef]

9. Ünal, N., Yanık, K., Karadağ, A., Odabaş1, H., Esen, S., Günaydin, M. (2014). Evaluation of the efficacy of akacid plus ${ }^{\circledR}$ fogging in eradicating causative microorganism in nosocomial infections. International Journal of Clinical and Experimental Medicine, 7(12), 5867-5871.

10. Abbasoğlu, U. (2009). Dezenfektanlar: Sinıflama ve Amaca Uygun Kullanımı, DAS Kongre Kitabı, Bilimsel Tıp Yayınevi.

11. İnan, A., Şenbayrak- Akçay, S., Özyürek, S.C., Tekin, S.Z., Erdoğmuş, P., Erdem, I., Engin, D.O., Ceren, N., Göktaş, P. (2009). The efficacy of various anticeptics and disinfectants against some nosocomial pathogens. Turk Mikrobiyoloji Cemiyeti Dergisi, 39(3-4), 97-102.

12. Harbarth, S., Tuan Soh, S., Horner, C., Wilcox, M.H. (2014). Is reduced susceptibility to disinfectants and antiseptics a risk in healthcare settings? A point/counterpoint review. Journal of Hospital Infection, 87, 194 -202. [CrossRef]

13. Hastane Enfeksiyonları ile Mücadele, Sayıştay Raporu, Bilimsel Tip Yayınevi, Ankara, (2009). From http://www.hider.org.tr/managete/fu_folder/PerformansDenetimi.pdf.

14. Fiçıcı, S.E., Durmaz, G., İlhan, S., Akgün, Y., Kosgeroğlu, N. (2002). Bactericidal effects of commonly used antiseptics/disinfectans against nosocomial pathogens and relationship between antibacterial and biocide resistance. Mikrobiyoloji Bulteni, 36(3-4), 259-269.

15. İrikli, S., Tatman, Otkun M. (2007). Investigation of in-vitro antimicrobial activities of some antiseptics and disinfectants. Turkish Journal of Infection, 21(1), 7-13.

16. Hedin, G., Blomkvist, A., Janson, M., Lindblom, A. (2012). Occurrence of potentially pathogenic bacteria on the hands of hospital patients before and after the introduction of patient hand disinfection. APMIS Journal of Pathology, Microbiology and Immunology, 120, 802-807. [CrossRef]

17. Clinical and Laboratory Standards Institute (CLSI) (formerly NCCLS). (2015). Performance Standards for Antimicrobial Susceptibility Testing 25th Informational Supplement. CLSI M100S25, Clinical and Laboratory Standards Institute, 940 West Valley Road, Wayne, Pennsylvania, USA.

18. Turkish Standard, TS/EN/1040:2005. (2005). Chemical disinfectants and antiseptics Quantitative suspension test for the evaluation of basic bactericidal activity of chemical disinfectants and antiseptics - Test method and requirements (phase 1). $1^{\text {st }}$ ed. Ankara.

19. Kawamura-Sato, K., Wachino, J., Kondo, T., Ito, H., Arakawa, Y. (2010). Correlation between reduced susceptibility to disinfectants and multidrug resistance among clinical isolates of Acinetobacter species. Journal of Antimicrobial Chemotherapy, 65, 1975-1983. [CrossRef] 
20. Nakipoğlu, Y., Gürler, B. (2004). An investigation on antibacterial efficacy of various disinfectants and antiseptics. Journal of ANKEM, 18(4), 220-223.

21. West, A.M., Teska, P.J., Lineback, C.B., Oliver, H.F. (2018). Strain, disinfectant, concentration, and contact time quantitatively impact disinfectant efficacy. Antimicrobial Resistance and Infection Control, 7, 49. [CrossRef]

22. Sultan, N. (2009). Dezenfektan Aktivitesini Etkileyen Faktörler ve Dezenfektan Etkinliğinin Değerlendirilmesi, DAS Kongre Kitabi, Bilimsel Tip Yayinevi, p. 121-137.

23. Erbay, A., Ergönül, O., Esener, H., Çolpan, A., Dokuzoğuz, B. (2002). Resistance of meticillin resistant Staphylococcus aureus, Acinetobacter spp. and Pseudomonas aeruginosa strains to various disinfectants. Turkish Journal of Hospital Infections, 6, 191-194.

24. Abbasoğlu, U. (2011). Dezenfeksiyon ve Dezenfektanlar, In: U. Abbasoğlu and A. Çevikbaş (Eds.), Efil Yayınevi: Ankara, (pp. 71-83).

25. Sudhaus, N., Nagengast, H., Pina-Perez, M.C., Martinez, A. (2014). Effectiveness of a peracetic acid-based disinfectant against spores of bacillus cereus under different environmental conditions. Food Control, 39, 1-7. [CrossRef]

26. Abdallah, M., Chataigne, G., Ferreira, Theret P., Benoliel, C., Drider, D., Dhulster, P., Chihib, N.E. (2014). Effect of growth temperature, surface type and incubation time on the resistance of Staphylococcus aureus biofilms to disinfectants. Applied Microbiology and Biotechnology, 98, 2597-2607. [CrossRef]

27. Raffellini, S., Schenk, M., Guerrero, S., Alzamora, S.M. (2011). Kinetics of Escherichia coli inactivation employing hydrogen peroxide at varying temperatures, $\mathrm{pH}$ and concentrations. Food Control, 22, 920-932. [CrossRef]

28. Macias, J.H., Arreguin, V., Munoz, J.M., Alvarez, J.A., Mosqueda, J.L., Macias, A.E. (2013). Chlorhexidine is a better antiseptic than povidone iodine and sodium hypochlorite because of its substantive effect. American Journal of Infection Control, 41, 634-637. [CrossRef]

29. Kampf, G., Höfer, M., Wendt, C. (1999). Efficacy of hand disinfectants against vancomycinresistant enterococci in vitro. Journal of Hospital Infection, 42, 143-150. [CrossRef]

30. Özalp, M., Ekizoğlu, M., Kılıç, E. (2007). Evaluation of bactericidal activity of certain gluteraldehyde free disinfectants used in the disinfection of endoscopes and surgical devices by a quantitative suspension test. Hacettepe University Journal of the Faculty of Pharmacy, 27(2), 131-138.

31. Sheraba, N.S., Yassin, A.S., Fahmy, A., Aminw, M.A. (2014). Quantitative suspension tests for the evaluation of bactericidal, fungicidal and sporicidal effects of biocides used in vaccine production facility. African Journal of Microbiology Research, 8(5), 417-424. [CrossRef]

32. Ünal, N., Karadağ, A., Yanık, K., Bilgin, K., Günaydın, M., Birinci, A. (2014). Analysis of in vitro efficiency of electrolyzed water against fungi species frequently detected in nosocomial infections. Universal Journal of Microbiology Research, 2(3), 50-55.

33. Rutala, W.A., Weber, D.J. (2013). Disinfection and sterilization: An overview. American Journal of Infection Control, 41(5), S2-S5. [CrossRef] 
34. Okesola, A.O., Olola, A.F. (2011). The efficay of the commonly used hospital disinfectants on Pseudomonas aeruginosa. International Research Journal of Microbiology, 2(7), 226-229.

35. İnan, A., Şenbayrak, Akçay S., Özyürek, S.Ç., Tekin, S.Z., Erdoğmuş, P., Erdem, İ., Engin, D.Ö., Ceran, N., Göktaş, P. (2009). The efficacy of various anticeptics and disinfectants against some nosocomial pathogens. Turk Mikrobiyoloji Cemiyeti Dergisi, 39(3-4), 97-102.

36. Tyski, S., Grzybowska, W., Grzeszczuk, S., Leszczynski, P., Staniszewska, M., Röhm-Rodowald, E., Jakimiak, B. (2009). Antimicrobial activity of glucoprotamin-containing disinfectants. Polish Journal of Microbiology, 58(4), 347-353.

37. Arias-Moliz, M.T., Ordinola-Zapata, R., Baca, P., Ruiz-Linares, M., Garcia, GarciaE., Hungaro, Duarte M.A., Monteiro, Bramante C., Ferrer-Luque, C.M. (2015). Antimicrobial activity of chlorhexidine, peracetic acid and sodium hypochlorite/etidronate irrigant solutions against Enterococcus faecalis biofilms. International Endodontic Journal, 48(12), 1188-1193. [CrossRef]

38. Kampf, G., Fliss, P.M., Martiny, H. (2014). Is peracetic acid suitable for the cleaning step of reprocessing flexible endoscopes? World Journal of Gastrointestinal Endoscopy, 6(9), 390-406. [CrossRef]

39. Costa, S.A.S., Paula, O.F.P., Silva, C.R.G., Leao, M.V.P., Santos, S.S.F. (2015). Stability of antimicrobial activity of peracetic acid solutions used in the final disinfection process. Brazilian Oral Research (online), 29(1), 1-6. [CrossRef]

40. Adukwu, E.C., Allen, S.C., Phillip, C.A. (2015). A comparison of the sensitivity of four staphylococcus aureus isolates to two chlorine-based disinfectants and an eco-friendly commercially available cleaning agent. International Journal of Environmental Health Research, 25(2), 115-125. [CrossRef]

41. Clasen, T., Edmondson, P. (2006). Sodium dichloroisocyanurate (NaDCC) tablets as an alternative to sodium hypochlorite for the routine treatment of drinking water at the household level. International Journal of Environmental Health Research, 209, 173-181. [CrossRef] 